\title{
Toe Walking Caused by Congenital Metabolic Diseases following a Specific Case
}

\author{
Bir Olgu Nedeniyle Doğumsal Metabolik Hastalıklara Bağlı Parmak Ucunda Yürüme
}

\author{
Işı| Özer (1) \\ Department of Pediatric Metabolism, Ondokuz Mayıs University School of Medicine, Samsun, Turkey
}

Cite this article as: Işıl Ö. Toe walking caused by congenital metabolic diseases following a specific case. Experimed 2018; 8(1): 37-40.

\section{ABSTRACT}

According to the literature on cases of toe walking, neural tube defects generally refer to orthopedic and neurologic case reports. The case of toe walking has been selected to present the information obtained from our patient group monitored for 6 years and to draw attention to Methylene Tetra Hydro Folate Reductase (MTHFR) polymorphisms. A 10 year-old female patient has was applied for toe walking and mild neurologic retardation. Her family history was unremarkable, except for family history of stroke in her grandfather. Her prominent clinical findings were obesity, sacral dimple and toe walking. The laboratory assessment showed that moderately high lipid levels and MTHFR A1298C heterozygote mutation. A hypoplasic disc, spondylolisthesis and filar lipoma were detected in a spinal MRI. The final diagnoses of $20 / 8000$ patients ( $11 \mathrm{fe}-$ male, 9 male) monitored in our clinic due to the symptoms of toe walking were as follows: 3 late diagnosed phenylketonuria (PKU), 2 metachromatic leuko-dystrophy (MLD), $1 \mathrm{~L}(\mathrm{OH})$ glutaric aciduria, 3 fatty acids oxidation defect (FAO), 1 mitochondrial disease and 10 MTHFR. A problem was detected in medium chain fatty acids in the patients with FAO. The complaint was considered to be muscle cramp due to increased muscle enzymes and aches throughout the complaint period. Considering neurological findings, the difficulties in walking were apparent in PKU and MLD patients. A short Achilles tendon was included in neurological findings in the patients diagnosed with L2 glutaric aciduria and mitochondrial diseases. From MTHFR patients, syringomyelia was found in one patient with sacral central line asymmetry and filar lipoma was detected in the remaining patients with deep sacral center lines whereas spondylolisthesis was observed in 2 patients and the presence of tethered cord was found in 1 patient. Toe walking refers to a finding defined as an early symptom of autism. MTHFR has been associated with autism. The autism like symptom was found only in one patient. The treatment of walking on the tip of the toe is not as simple as achieving success with local Achilles tendon surgery alone. It would be vital to find out the underlying cause.

Keywords: Toe walking, congenital metabolic diseases, autism, MTHFR

\section{öz}

Parmak ucunda yürüme ve nöral tüp defektleri, genellikle nörolojik ve ortopedik olgu sunumları olarak yayınlarda sunulmaktadır. Altı yıllık poliklinik tecrübemiz nedeniyle parmak ucunda yürümede Metilen Tetra Hidro Folat Redüktaz (MTHFR) polimorfizmlerine dikkat çekmek için bu olgu seçildi. On yaşındaki kız hasta parmak ucunda yürüme ve hafif nörolojik gerilikle başvurdu. Aile öyküsünde anneannede inme dışında önemli bulgu yoktu. Öne çıkan klinik bulguları obezite, sakral gamze ve parmak ucunda yürümeydi. Laboratuvar değerlendirmesinde orta derecede lipid yüksekliği, MTHFR A1298C heterozigot mutasyonu görülmekteydi. Spinal manyetik rezonans görüntüleme (MRI) ile incelemede hipoplazik disk, spondilolistezis ve filar lipom tespit edildi. Klinik hasta izlemimiz sırasında 8000 hastanın 11 kız 9 erkek cinsiyette olan toplam 20 hastada parmak ucunda yürüme tespit edildi. Bunların hastalıklara göre dağılımı 3 geç tanı fenilketonüri (PKU), 2 metakromatik lökodistrofi (MLD), $1 \mathrm{~L}(\mathrm{OH})$ glutarik asidüri, 3 yağ aside oksidasyon bozukluğu (FAO), 1 mitokondriyal hastalık ve 10 MTHFR şeklindeydi. FAO grubunda ağrılı kas kramp atakları ve kas enzim artışları sırasında parmak ucunda yürüme gözlenmiști. PKU ve MLD'li hastalarda kalıcı nörolojik sorunlarla parmak ucunda yürüme ilişkisi görülmekteydi. Kısa Aşil tendonu L2 $(\mathrm{OH})$ Glutarik asidüri hastası parmakucunda yürüme nedeniydi. MTHFR'li hastalarda nöral tüp defektleri ön plandaydı ( 1 sirengomiyeli, 1 filar lipom, 2 spondilolistezis ve 1 gergin kord). Erken döneminde parmak ucunda yürüme tanımlanan otizm etiolojisinde MTHFR de yer almaktadır. Hastalarımızdan birinde otizm tanısı vardı. Parmak ucunda yürüme sadece Aşil tendon ameliyatı ile düzeltilebilecek kadar basit bir sorun değildir. Altta yatan sorunun araştırılması gerekir.

Anahtar Kelimeler: Parmak ucunda yürüme, kalıtsal metabolik hastalıklar, Otizm, MTHFR 


\section{INTRODUCTION}

In the medical literature, the causes of toe walking are thought to be storage diseases leading to neuromuscular involvement, mitochondrial diseases and urea cycle disorders (1). Furthermore, toe walking is also reported as an early symptom of autism $(2,3)$. According to the literature on cases of toe walking, neural tube defects generally refer to orthopedic and neurologic case reports affiliated with spinal deformities or case series considered as atypical due to the lack of definition in such reports (1, 4-9). However, signs of Methylene Tetra Hydro Folate Reductase (MTHFR) polymorphisms in etiologies of autism and neural tube defects fail to be found in congenital metabolism diseases and neurology-oriented journals. The case of toe walking has been selected to present the information obtained from our patient group, who were monitored for 6 years, and to draw attention to MTHFR polymorphisms as the primary cause found by searching similar complaints from the patients monitored in our clinic for neuro-motor deficiencies.

\section{CASE PRESENTATION}

A 10-year-old woman was admitted due to walking on her finger tip and poor schooling. The patient born prematurely (27th gestational week) with neonatal jaundice and a history of exchange transfusion had walked on her tiptoes since her first

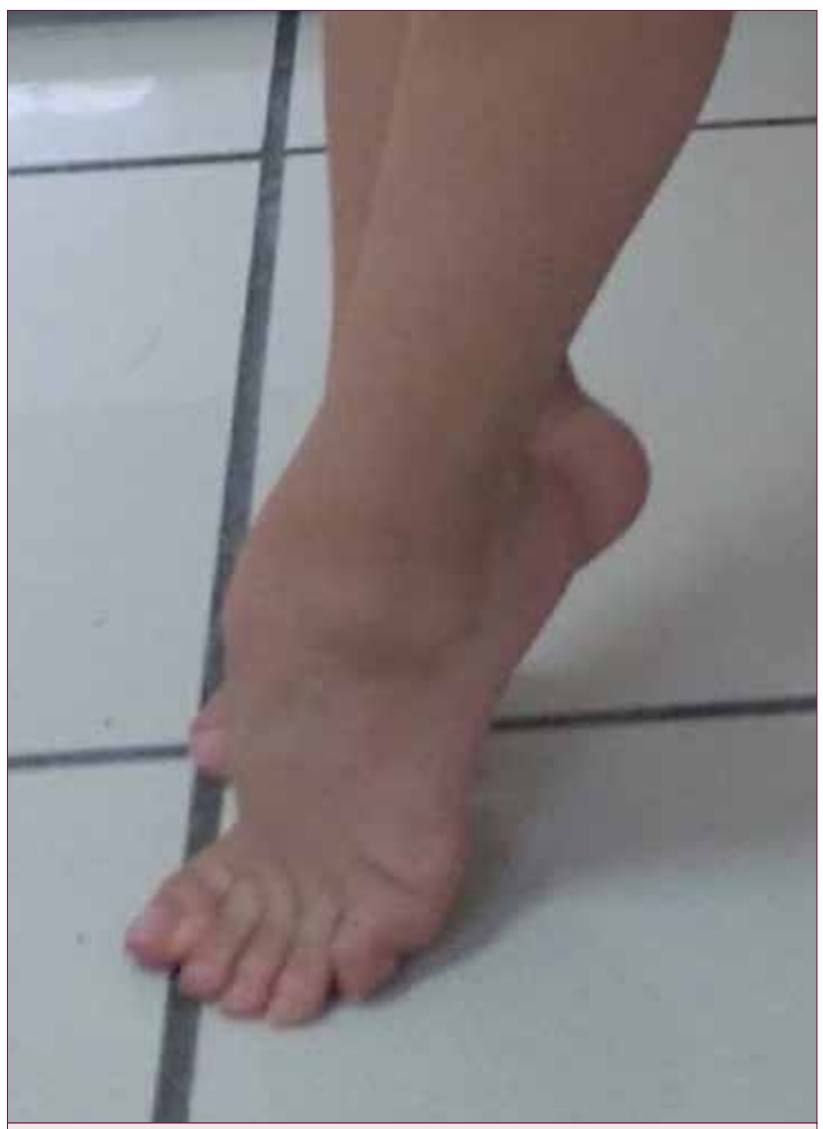

Figure 1. Toe walking steps, however, the patient's neurological development complied with her age. As the patient had been unable to stand at school, she was sent to our polyclinic for metabolic assessment.

The patient with healthy parents from unrelated families and healthy brothers aged 11 and 7 has a family history of stroke in her grandfather but symptoms were not found in neonatal screening. The weight-for-height rate was measured as $45 \mathrm{~kg}$ to $136 \mathrm{~cm}$ whereas relevant characteristics were not available in other systems excluding the cases of apple type obesity, strias, sacral dimple and toe walking (Figure 1) in physical examination.

Hemogram levels were found to be normal in laboratory assessment as well as blood glucose rate, electrolytes, liver and kidney functions, muscle enzymes, B12 level and folate, homocysteine and insulin levels. The cholesterol level was $238 \mathrm{mg} / \mathrm{dl}$ whereas the triglyceride level is $211 \mathrm{mg} / \mathrm{dl}$. In tandem screening, it was observed that $\mathrm{C} 8, \mathrm{C} 10$ and $\mathrm{C} 10: 1$ levels were high. Neuroradiologic reexamination of the patient revealed normal results from cranial MRI, lumbar spinal MRI and EMG processes 12 years ago, hypoplasic disc and spondylolisthesis were detected in an entire spinal MRI at the filarlipoma rate $(1.7 \mathrm{~mm})$ between T9 and T10 (Figure 2). In addition, MTHFR 1298 c Heterozygote mutation was detected during a genetic examina-

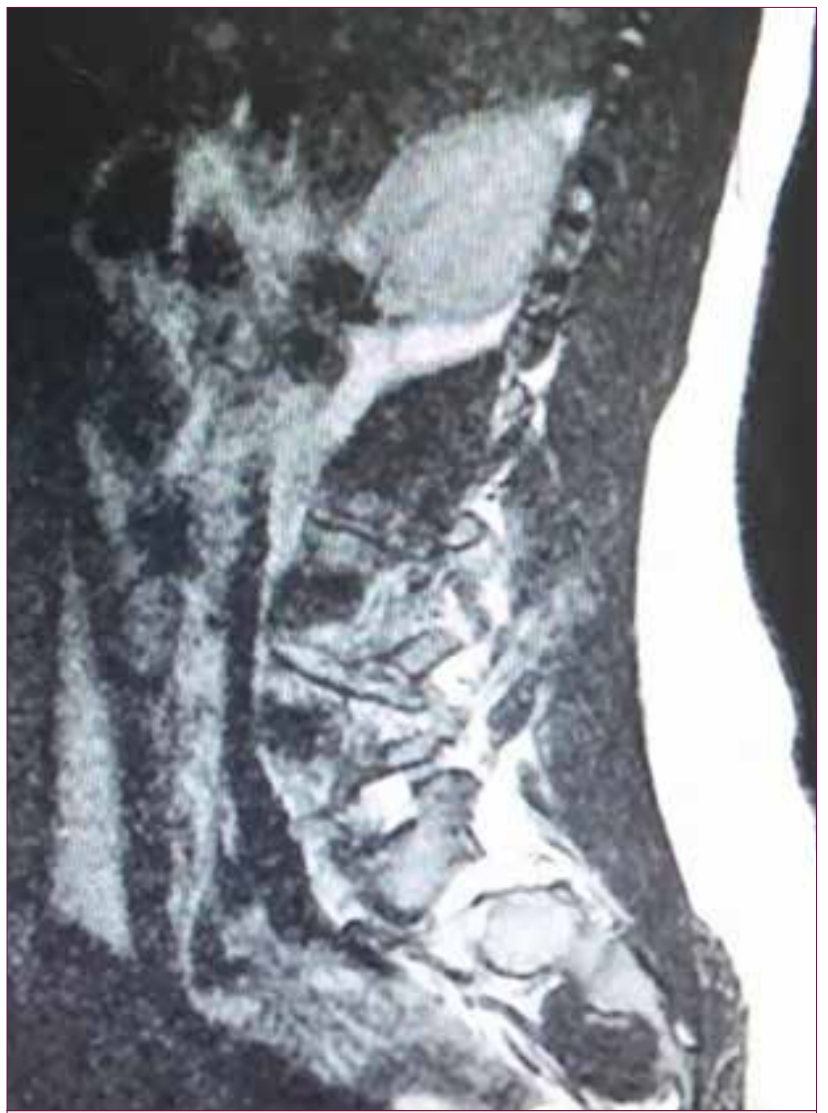

Figure 2. Hypoplasic discs, spondylolisthesis and filar lipoma is showed in spinal Magnetic Resonance Imaging 
Table 1. Clinical ethiologic disturbition of the patients with toe walking

\begin{tabular}{llll}
\hline Disease Groups N:20 & $\mathbf{N}(\%)$ & Special note & \\
\hline $\begin{array}{l}\text { Methylenetetra hydro reductase deficiency } \\
\text { polymorphysims }\end{array}$ & $10(50)$ & $\begin{array}{l}\text { No vetrebral pathology } \\
\text { Spondylolisthesis } \\
\text { Syrengomyelia }\end{array}$ & $\begin{array}{l}\text { 2 patients } \\
\text { 1 patient }\end{array}$ \\
& & $\begin{array}{l}\text { Filar lipoma } \\
\text { Tethered cord }\end{array}$ & $\begin{array}{l}\text { 1 patient } \\
\text { Autism }\end{array}$ \\
& & Latient \\
\hline Phenylketonuria & $3(15)$ & Late diagnosed patient (Neurologic pathology) \\
\hline Fatty Acid Oxidation defects & $3(15)$ & During acute symptomatic period \\
\hline Methocromatic Leucodystrophy & $2(10)$ & Short Achilles tendon and neuromotor pathology \\
\hline Mitocondrial Diasease & $1(5)$ & Neuromotor pathology \\
\hline LOH Glutaric Aciduria & $1(5)$ & Short Achilles tendon and neuromotor pathologyv \\
\hline
\end{tabular}

tion required for sacral dimple. The carnitine (Carnitene; Santa Farma Medical, Istanbul, Turkey) was loaded to the patient at the rate of $100 \mathrm{mg} / \mathrm{kg} /$ day together with folate (Folbiol; ibrahim Ethem Ulugay Medical, İstanbul, Turkey) at the rate of 2.5 $\mathrm{g} /$ day. In tandem screening performed during medical control after 2 weeks, free and acyl carnitine profile and urinary organic acid analysis were found normal. L-Carnitine (Carnitene;Santa Farma medical, Istanbul, Turkey) loading was ceased while folate application continued. The patient was also directed to neurosurgical monitoring.

\section{DISCUSSION}

The final diagnoses of 8000 patients monitored in our clinic for 6 years for symptoms of toe walking were as follows: from the 20 patients ( 11 females and 9 males) late diagnosed phenylketonuria was found in 3 patients (PKU), 2 had metachromatic leuko-dystrophy (MLD), 1 had L $(\mathrm{OH})$ glutaricaciduria, 3 had fatty acids oxidation defect (FAO), 1 had mitochondrial disease and 10 had methylene tetra hydro folatereductase (MTHFR) (Table 1). A sacral dimple was present in only one person among all the MTHFR patients although any finding related to the spiral channel was not found on examination of the remaining patients. A mutation check was required for the patients due to MTHFR suggestive symptoms in family medical history including stroke, early Ml, abortus in mother and epilepsy. A problem was detected in medium chain fatty acids in the patients with fatty acid oxidation. The case of toe walking was only defined during the attacks. The complaint was considered to be muscle cramp due to increased muscle enzymes and aches throughout the complaint period. Considering neurological findings, the difficulties in walking were apparent in PKU and MLD patients. A short Achilles tendon was included in neurological findings in the patients diagnosed with L2 glutaricaciduria and mitochondrial diseases. From MTHFR patients, syringomyelia was found in one patient with sacral central line asymmetry and filarlipoma was detected in the remaining patients with deep sacral center lines and spondylolisthesis was observed in 2 patients and the presence of a tethered cord was found in 1 patient. Since toe walking refers to a finding defined as early symptom of autism in literature and MTHFR was associated with autism, the patients were examined in respect to autism. Autism like symptoms were found only in one patient.

The case of toe walking could be affiliated with metabolic diseases. Especially of MTHFR with its standing in neural tube etiology and its relatively increased frequency among society in comparison to other diseases due to hereditary risks and the exposure to more than one system, it is also required to consider fatty acid oxidation defects, mitochondrial diseases, storage disorders leading to neuro-motor involvement, organic academia and late diagnosed classical phenylketonuria with neurological sequels.

The treatment for toe walking is not a simple case to be recovered locally (by means of Achilles tendon surgery). It is vital to find out the underlying cause.

Informed Consent: Written informed consent was obtained from the parents of the patient who participated in this study.

Peer-review: Externally peer-reviewed.

Conflict of Interest: The author declared no conflict of interest.

Financial Disclosure: The author declared that this study has received no financial support.

Hasta Onamı: Yazııı hasta onamı bu çalışmaya katılan hastanın ailesinden alınmıştır.

Hakem Değerlendirmesi: Dış bağımsız.

Çıkar Çatışması: Yazar herhangi bir çıkar çatışması olmadığını bildirmiştir.

Finansal Destek: Yazar bu çalışma için hiçbir finansal destek alınmadığını beyan etmiştir. 


\section{REFERENCES}

1. Vavken P, Kathleen A, Ganal-Antonio B, Shen F.H, Chapman, JR, Samartzis D. Fundamentals of clinical outcomes assessment for spinal disorders: study designs, methodologies, and analyses. Global Spine J 2015; 5: 156-64.[CrossRef]

2. Accardo PJ, Monasterio EO, Oswald D. Toe walking in autism. Patel VB, Preedy VR, Martin CR, editors. The Comprehensive Guide to Autism. New York: Springer; 2014: p.519-532.

3. Barrow WJ, Jaworski $M$, Accardo PJ. Persistent toe walking in autism. J Child Neurol 2011; 26: 619-21. [CrossRef]

4. O'Neill BR, Gallegos D, Herron A, Palmer C, Stence NV, Hankinson $\mathrm{TC}$, et al. Use of magnetic resonance imaging to detect occult spinal dysraphism in infants. J Neurosurg Pediatr 2017: 19; 217-26. [CrossRef]
5. Donmez FY, Basaran C, Ulu EM, Guvenc Z, Tarhan NC. Unusual association of tethered cord, filum terminale lipoma, and myxopapillary ependymoma. Spine (Phila Pa 1976) 2008; 33: E849-51. [CrossRef]

6. Souweidane MM, Drake, JM. Retethering of sectioned fibrolipomatous filum terminales: report of twocases. Neurosurgery 1998: 42; 1390-3. [CrossRef]

7. Kucera JN, Coley I, O'Hara S, Kosnik EJ, Coley BD. The simple sacral dimple: Diagnosticyield of ultrasound in neonates. Pediatr Radiol 2015: 45; 211-6. [CrossRef]

8. Williams $C M$, Tinley $P$, Curtin $M$, Nielsen $S$. Vibration perception thresholds in children with idiopathic toe walking gait. J Child Neurol 2012; 27: 1017-21. [CrossRef]

9. Stone JJ, Rozzelle CJ. Retethering of sectioned fibrolipomatous filum terminale in an adult: case report and review of the literature. Spine J 2010; 10: e1-e4. [CrossRef] 